\title{
個体群動態モデルの生息場評価手法 への導入に関する基礎的研究 \\ FUNDAMENTAL STUDY ON APPLICATION OF THEORY OF POPULATION DYNAMICS TO HABITAT EVALUATION METHOD
}

\author{
田代喬 $1 \cdot$ 加賀真介 ${ }^{2} \cdot$ 辻本哲郎 3 \\ Takashi TASHIRO, Shinsuke KAGA and Tetsuro TSUJIMOTO \\ 1学生会員 工修 名古屋大学大学院博士 (後期) 課程学生 工学研究科地圈環境工学専攻 \\ ( (464-8603 名古屋市千種区不老町) \\ 2学生会員 名古屋大学大学院博士 (前期) 課程学生 工学研究科地圈環境工学専攻 \\ 3 正会員 工博 名古屋大学大学院教授 工学研究科地圈環境工学専攻
}

\begin{abstract}
Population dynamics is one of the important topics of ecology. It has been employed to simulate changing situation of living species by using mathematical models. Today, it is introduced to the field of environmental engineering. By the way, there is another model that discuss about habitat evaluation method in the river engineering. Each of the models has been progressed individually.

In this study, we tried to innovate the population dynamics to develop the habitat evaluation method. By discussing about the dynamics of algal growth and the habitat suitability of algae in the middle reach of the Yahagi River, we may identify the theory of population dynamics as one of the necessary viewpoints for habitat evaluation.
\end{abstract}

Key Words : population dynamics, habitat evaluation method, bed-load transport, growth and detachment rate of algae

\section{1. まえがき}

個体群動態モデル11は，ある個体群における個体数の 時間的変動を予測する手段として, 数理生態学の分野に おける根幹となっている. 増殖率, 死亡率などの様々な パラメータを，実現象に則して設定することにより，生 態系に関する諸問題の解明に貢献してきた。河川工学の 分野でも，浅枝2)，楠田尔を始めとする研究者がその導入 を試み, 生物現象の工学的把握に大きな成果をあげてい る.一方，同じく生物現象を工学的に取り扱ってきた研 究として, 生息場評価に関するものがあり, 数多くの研 究が行われている。しかしながら, 両者の特長には若干 の違いが存在するため，これらを統合しようとする試み はなされていない. 生物を対象にする場合, それが本来 開放系である1)との考えに基づいているため, 個体群動 態は空間的スケールに関する取り扱いが噯昧であるので, 限られた空間に定着して生育するような植物を対象とす る2)か，非常に大きな空間内における動植物の傾向（あ る個体群の絶滅の可能性など）を把握することに用いら れてきた。 それに対し, 生息場評価は, その場所の物理
環境をもとに生息適性を求めることが多く, 生物の環境 に対する反応速度というものが考慮されていない上に， 時々刻々と変化する河川の物理環境を対象とする難しさ から，生息適性=生息状況となるような環境変化に対す る反応速度の速い動物（魚類など）を対象とすることが 多かった。

著者らは，河川生態系の総合的な評価を目指し，生息 場評価に関する研究を進める中，その対象を魚類・底生 動物から付着藻類へと広げてきた。その過程において, 魚類については, 生活史における生息場の時空間構造を 考虑した評価手法4)を考案し, 付着藻類については，生 息適性=生息状況という図式が成り立たない中で，個体 群動態モデルの手法を援用して繁茂動態を予測する5な どの成果をあげてきた. 個体群動態モデルは, これまで の生息場評価で十分に議論出来なかった時間的変化を取 り扱うことのできる有効な手段であると考えられる。 そ こで, 本研究では, 対象とすべき生物のうち, 付着藻類 の繁茂動態に着目する. 矢作川中流域における付着藻類 繁茂の実態に関する資料・調査をもとにした考察を行つ た上で，その繁茂動態を予測し，個体群動態モデルの生 息場評価手法への導入に関する検討を行う。 


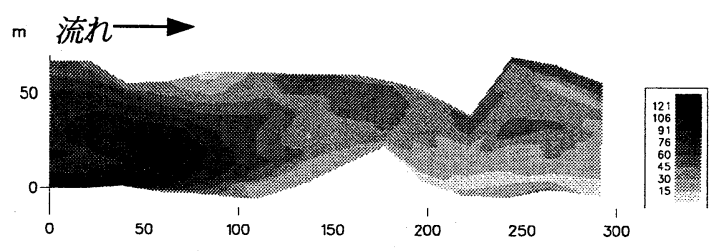

図-1 矢作川対象リーチでの水深 $(\mathrm{cm})$ の空間分布

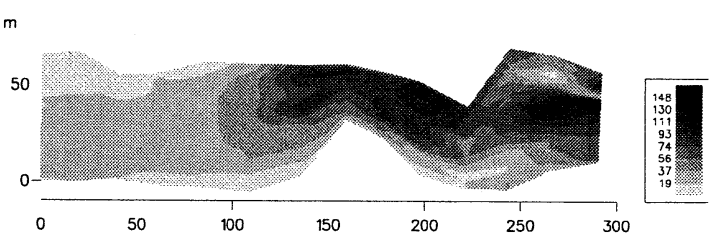

図-2 矢作川対象リーチでの流速 $(\mathrm{cm} / \mathrm{s})$ の平面分布

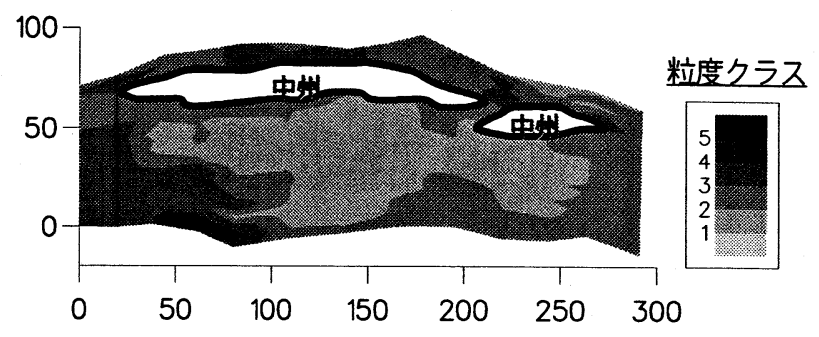

図-3 矢作川対象リーチでの底質粒径分布

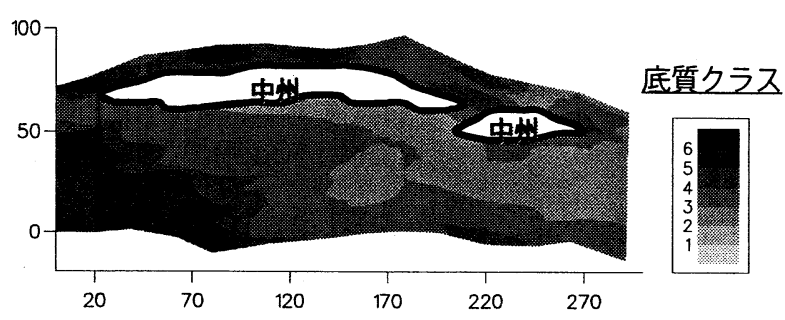

図-4 矢作川対象リーチでの底質構造類型の分布

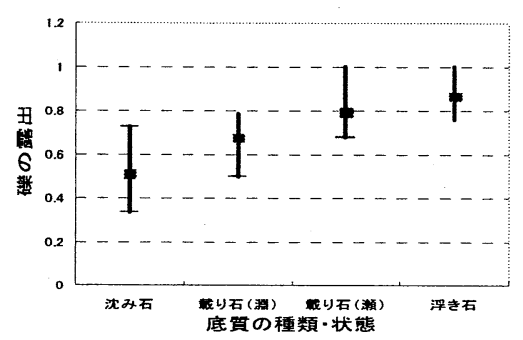

図-5＼cjkstart底質構造類型と碟の露出率

質クラスの平面分布として表したのが図-3,4である.

次に，矢作川のこのセグメントでは，主として $1 \mathrm{~cm}$ 以 下の砂集団と玉石層を構成する粒径 $5 \mathrm{~cm} \sim 20 \mathrm{~cm}$ 集団の組 み合わせで河床が構成されていることから，砂面と磁面 の相対位置で先に定義した（浮き石,沈み石といった） 定性的な底質構造類型を定量評価できると考え，その関 係を図-5で調べた. 図には類型ごとの碟の平均露出率と その最大・最小值を示した。

\section{（2）付着藻類の繁茂状況調查}

付着藻類の群集の中でも，系状藻類の卓越するものは， 䚓乱の少ない状態が一定期間続いたあとに生じる極相状 態であると考えられる，矢作川中流域では，近年，河川 環境の変化に伴い，系状藻類カワシオグサ (Cladophola glomerata）の異常繁茂が顕在化している. 系状藻類は， 他の藻類と比較すると, 肉眼で確認できるほど大型であ り，礫面における繁茂状態を比較的容易に調査可能であ ることから，対象区間全域で目測によって植被率の平面 分布を調べた。植被率レベルの判別に当たって，次のよ うな5段階のクラス分けを利用した。 (1)植被率が 0 ～5\%， (2) $5 \sim 25 \%$, (3) $25 \sim 50 \%$, (4) $50 \sim 75 \%$, (5)75 100\%. 図-6には，10月19日及び22日，11月14日の調査結果から， 系状藻類の植被率レべルの平面分布を表示する. 図より 植被率レベルは，比較的高いレベルを持つ区間が10月と 

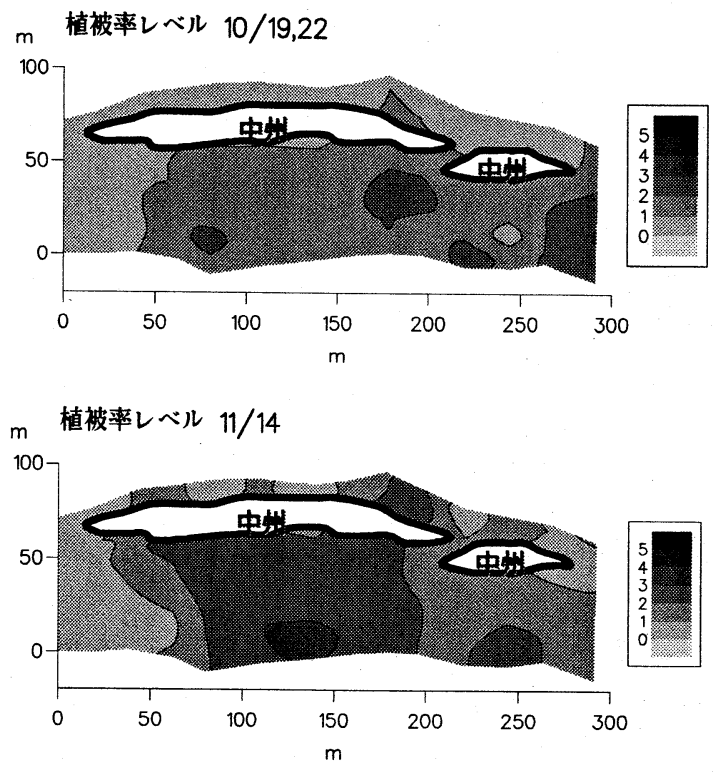

図-6 糸状藻類植被率の空間分布

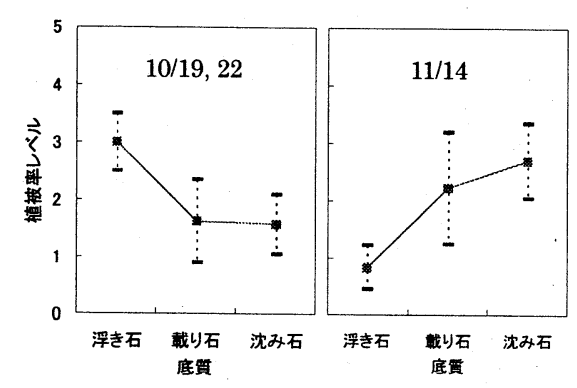

図-7 藻類植被率 (平均值, 標準偏差) と底質構造類型の関係

11月で異なった傾向が見られる.すなわち，10月の時点 では150mより下流の早瀬の区間で繁茂しているのに対 し，11月の時点では，それより上流の平瀬区間で繁茂し ている様子が見てとれる. 流速, 水深といった物理量そ のものを生育環境適性指標に直接選択できないことが示 唆される.もっとも敏感に変化した指標は図-7に示すよ うに底質構造であるが，2度の調査で相反する結果と なっている．これは植被率がそれまでの生育適性の累積 の結果であるためで，生育環境としては流況を媒介とし た履歴性の考慮が重要となる。 そこで本研究では, 生育 適性を增殖適性と捉え，藻類の消長過程の解析を試みる。

\section{3. 付着藻類の生息動態予測手法}

一般に, 生物の生長過程はロジスティック曲線に従う 場合が多い1). 本章では付着藻類カワシオグサの繁茂動 態を予測するにあたり，著者らの手法りに従った。すな わち, 植被率を $A$, 飽和植被率 $A_{\max }$ として与えられる相 対植被率 $A^{*}=A / A_{\text {max }}$ をパラメータとして, 次式で取り扱う.

$$
\frac{\mathrm{d} A^{*}}{\mathrm{~d} t}=(\varepsilon-p) A^{*}-\varepsilon A^{* 2}
$$
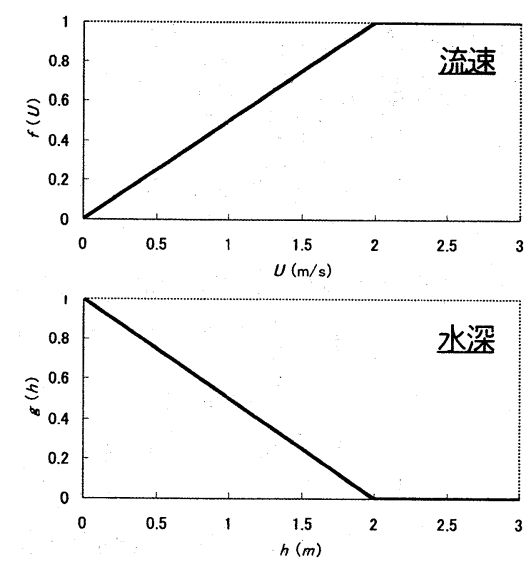

図-8 生長率に関する流速, 水深の影響関数

ここで, $\varepsilon:$ 生長率, $p:$ 剥離率であり, 河床の状態, 流 量によって変化する量である. 上式の解は, $t=0$ で $A^{*}=A_{0}^{*}$ として, 次のように書ける.

$$
A^{*}=\frac{1}{\frac{\varepsilon}{\varepsilon-p}+\left(\frac{1}{A_{0}^{*}}-\frac{\varepsilon}{\varepsilon-p}\right) \exp \{-(\varepsilon-p) t\}}
$$

生長率は, 栄養塩の補給, 光エネルギ一供給, 藻類の 遷移に関係する.ここでは, 白金”のモニタリング調査 結果を参考に, 次の3通りの生長率を設定した. (1)水理 条件によらず一定であるとして， $\varepsilon_{1}=0.05\left(\mathrm{day}^{-1}\right)$ としたも の, (2)大きな流速は, 系状緑藻のマット内の不要物を洗 い流し, 栄養塩をマットのより梁部にまで行き渡らせて 生育を促進する効果がある ${ }^{8)}$-10) と考え, 流速の関数 (式 （3)参照）としたもの，(3)(2)の効果に加え，水深による 日照度の違いによる効果 ${ }^{8-10)}$ を考慮して, 流速, 水深の 関数（式(4)参照）としたものである.

$$
\begin{gathered}
\varepsilon_{2}=\beta \times f(U) \\
\varepsilon_{3}=\beta \times f(U) \times g(h)
\end{gathered}
$$

ここに， $\beta$ : 最大生長率 (ここでは, 0.1 とする),$f$, $g$ : 流速 $(U)$, 水深 $(h)$ についての影響関数 (図-8参 照) である。(2),(3)のような生長率の設定手法は,

PHABSIM (Physical HABitat SIMulation) における生息 適性評価値の算定手法に倣ったものである. 従って, こ こでの生長率は従来の生息場評価における生息適性をも 表現するものである.

一方, 剥離率 $p$ は㩇乱に支配されるため, 河床砂間や 鿬上の砂輸送と掃流砂の衝撃による藻類剥離モデルを関 連付けて設定する.ここでの攪乱は, 河床のアーマー化 が進行した矢作川の現状 ${ }^{11)}$ に鑑み，基盤の碟は移動しな いが，砂が碟間あるいは碟上を移動することによって礫 表面が受ける衝撃によるものと考えた.

河床䃯間や碟上の砂輸送に関しては，以下のモデルに 従った. 対象リーチにおける底質粒径 (図-3参照) 及び 


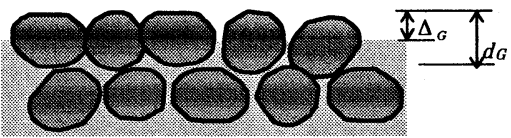

図-9 アーマー化路床のモデル

底質構造類型（図-4参照）から，底質を碟（粒径 $\left.d_{\mathrm{G}}=10 \mathrm{~cm}\right)$ ，砂（粒径 $d_{\mathrm{S}}=1 \mathrm{~mm}$ ）の2種から構成されるも のとし, 鿬頂部の高さと砂面の高さの差を $\Delta_{\mathrm{G}}$ として, 図-9のようにモデル化して考える.これは，2での底質 構造類型の議論と対応したもので,「磁の露出率」は $\Delta_{\mathrm{G}} / d_{\mathrm{G}}$ で定義される.このとき，河床の等価砂粗度 $k_{\mathrm{S}}$ は， $\Delta_{\mathrm{G}}$ と $d_{\mathrm{S}}$ との和で与えられるものとし, 単位幅流量 $q$ とエ ネルギー勾配 $I_{\mathrm{e}}$ 㝍えられたときの水深を式(5)で求める.

$$
h=\left\{\frac{\left(\Delta_{G}+d_{s}\right)^{1 / 3} q^{2}}{7.66^{2} g I_{e}}\right\}^{3 / 10}
$$

ここに，gは重力加速度である. また, 砂面は突出した 礫の生む流れで遮蔽されるため, 有効摩擦速度を見積も るのに芦田・藤田 ${ }^{12)}$ に做って遮蔽係数 $k$ を導入する. これ より, 砂面有効無次元掃流力『称次式のように書ける.

$$
\tau_{*_{e}}=k^{2} \tau_{*}=\frac{k^{2} h I_{e}}{(\sigma / \rho-1) d_{s}}
$$

芦田・藤田 ${ }^{12}$ および道上ら ${ }^{13)}$ の実験結果を元に, 遮蔽係数 をさしあたって次式で見積もることとする.

$$
k^{2}=1-\frac{\Delta_{G}}{d_{G}}
$$

このようにして見積もられた有効掃流力を, 芦田・道上 式 ${ }^{14)}$ に適用して砂間を流送される流砂量を評価する。

掃流砂の衝撃による藻類剥離モデルに関しては, サル テーション粒子の衝撃力でカワシオグサが剥離する過程 を扱った著者ら ${ }^{15)}$ のデルを採用した.すなわち，サル テーション運動する砂が砂に衝突する際に，礫面になす 単位面積・単位時間あたりの仕事量を $W_{\mathrm{x}}$ として, 次の ように書ける。

$$
p=(24 \mathrm{x} 3600) \alpha W_{x} \quad\left(\text { day }^{-1}\right)
$$

ここで， $\alpha$ : カワシオグサの剥離抵抗を表す係数であり， 長さ $3 \mathrm{~cm}$ 程度のカワシオグサについては, $1.23 \times 10^{-4} \mathrm{~N}^{-1} \mathrm{~m}$ が適当であった. なお， $W_{\mathrm{x}}$ につては，石橋目による滑 面上でのサルテーション運動解析をもとに，次のように 書ける.

$$
W_{x}=\gamma q_{B} d_{s}^{1 / 3} u_{e}^{2 / 3}
$$

ここで， $\gamma$ : 礫の材料特性に関わる係数であり， $4.94 \times$ $10^{5} \mathrm{Nm}^{4} \mathrm{~s}^{2 / 3}$ が適当とされた。

さて，実際に繁茂動態の解析に当たっては，流量の変 動を有限の時間ステップごとに与えることから，式(2) をそれぞれの時間ステップごとに適用して，カワシオグ

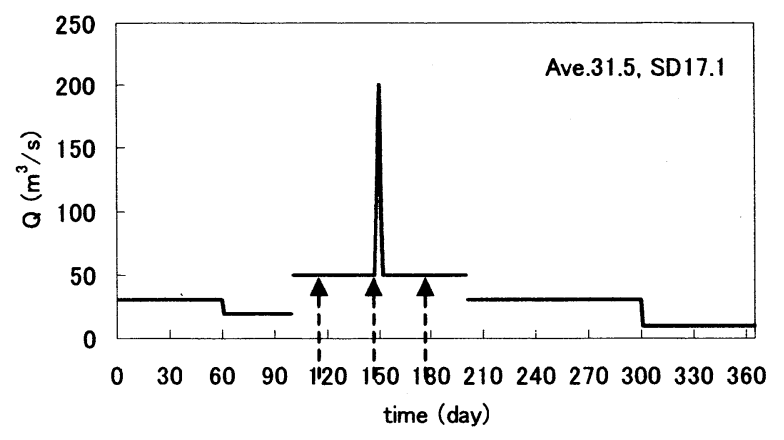

図-10 解析対象流況の日変化 (矢印は, 後図と対応)

サの消長を解析する.このとき，時間ステップを $\Delta t$ とす れば，時間ステップごとのカワシオグサの無次元植被率 $A_{\mathrm{e}}^{*}$ についての漸化式は次のようである.

$$
A_{i+1}^{*}=\frac{1}{\frac{\varepsilon}{\varepsilon-p_{i}}+\left(\frac{1}{A_{i}^{*}}-\frac{\varepsilon}{\varepsilon-p_{i}}\right) \exp \left\{-\left(\varepsilon-p_{i}\right) \Delta t\right\}}
$$

添字 $i$ : 時間ステップiにおける量であることを示す.

\section{4. 生息動態予測モデルと生息場評価}

前章の生息動態予測モデルの有効性を検討するための 第一段階として, 従来の生息場評価との比較, 考察を行 う必要がある.そこで，藻類の増殖率・剥離率を反映さ せた生息場評価を行うために，ここでの検討には，cost

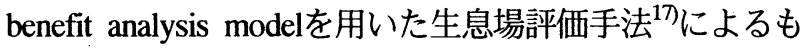
のを援用した。すなわち，costを剥離率，benefitを増殖 率に対応するものとすれば，増殖率/剥離率 （benefit/cost）により評価値の算出が可能である. 本章 では，(1)対象河道・流況を設定, 平面2次元水理解析 ${ }^{4}$ によって水理特性を把握した上で，(2)cost benefit analysis modelを用いた生息場評価，(3)付着藻類繁茂動 態シミュレーションを行い，(4)両者の考察を通した検 討を行う.

\section{（1）対象河道·流況の設定}

対象河道について，2で示した矢作川対象リ一チの河 道特性である砂州地形を意識し，現地スケールを参照し て次式によって与えるものとする.

$$
z_{b}=-i_{b} x+A \cos \left\{\left(\frac{2 \pi}{2 B}\right) y\right\} \sin \left\{\left(\frac{2 \pi}{L}\right) x\right\}
$$

ここに, $z_{b}:$ 河床高さ, $x:$ 縦断方向距離, $y:$ 横断方向 距離， $i_{b}$ : 平均河床勾配 $(1 / 670), A$ : 砂州の半波高 $(1.5 \mathrm{~m}), B$ : 河幅 $(120 \mathrm{~m}), L$ : 砂州波長 $(1200 \mathrm{~m})$ である. また，浮き石帯・沈み石帯に代表される底質の 構成・構造を簡易に取り扱うため, 以下に示す著者らの 

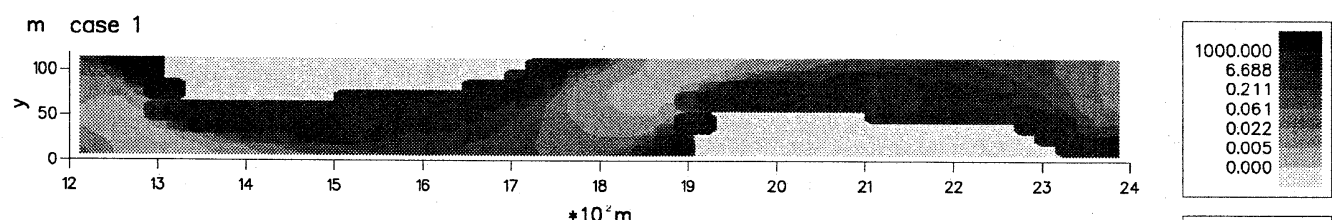

$m$ case $2(f)$

$x$

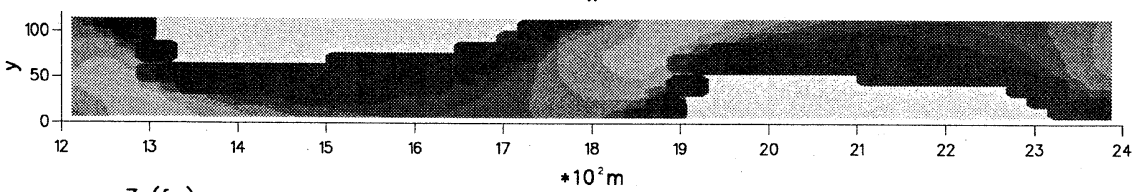

$m$ case $3(f, g)$

$\mathrm{x}$
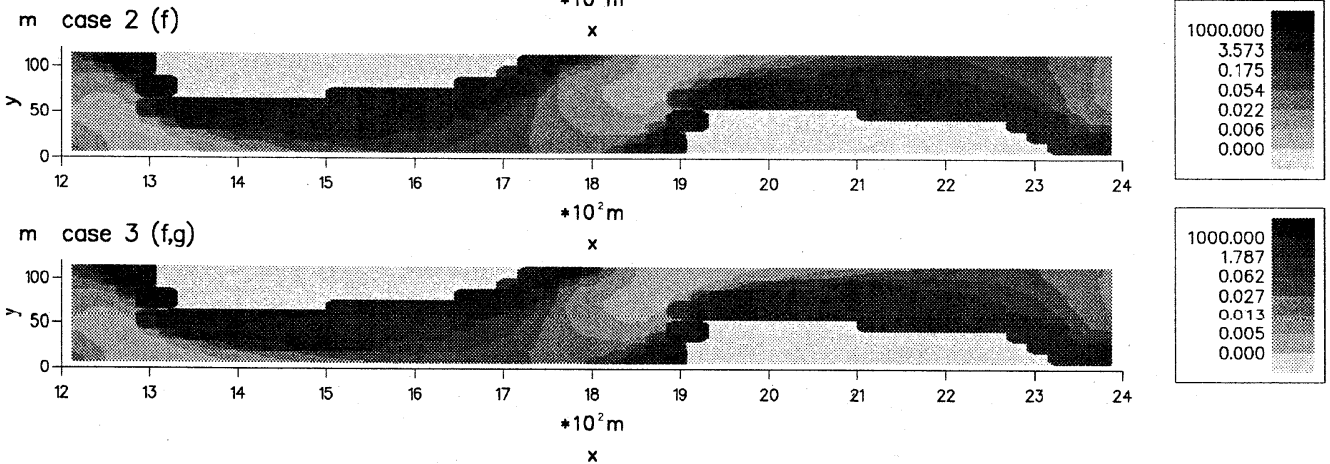

図-11 cost benefit analysis modelを用いた生息場評価による藻類の評価値 $(\mathrm{B} / \mathrm{C})$ コンター図 (流量 $50 \mathrm{~m}^{3} / \mathrm{s}$ 時)
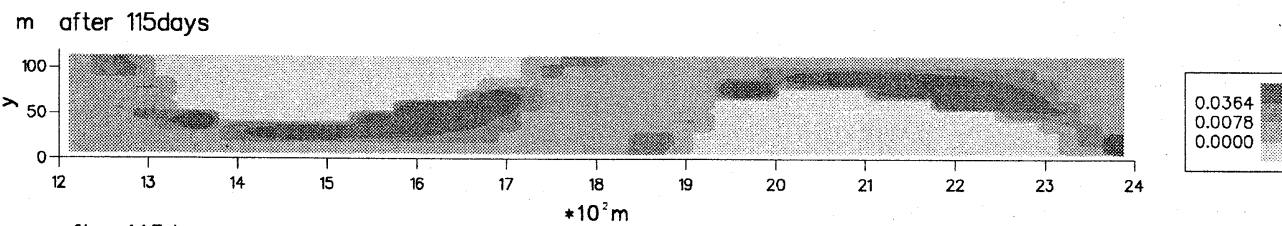

$m$ after 145days
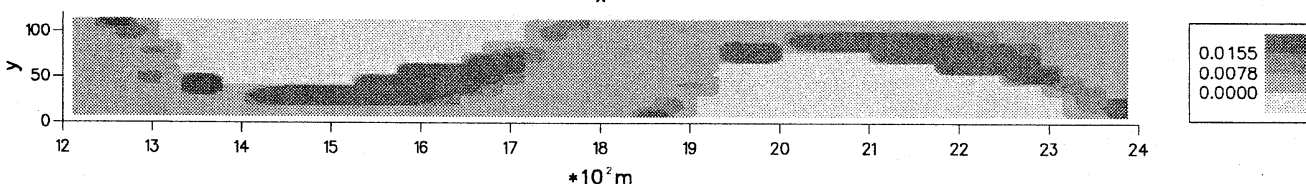

$m$ after 175days

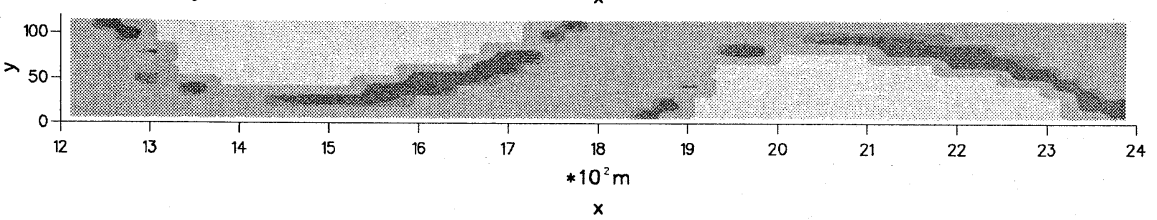

図-12 繁茂動態シミュレーションによる付着藻類の無次元植被率コンター図（流量 $50 \mathrm{~m}^{3} / \mathrm{s}$ 時）

手法)に従い，礫の露出率をパラメータとして，底質の 数值的な表現を試みた。河床材料としては，砂 $(10 \mathrm{~cm})$ と砂 $(1 \mathrm{~mm})$ の2粒径を与える. 解析の初期条 件として，礫層の上に薄く砂が載つた河床を想定した上 で，流れ場を計算することによって $\tau_{*}$ を求める一方, $\tau_{* e}=\tau_{* c}\left(\tau_{* c}:\right.$ 無次元限界掃流力 $)$ とおいて, 式(6), (7) の関係から碟の露出率を推定する。これは，最終的な碟 の露出率は砂が動かなくなった時点で得られると考えた ためである. 碟の露出率に応じた粗度を設定し直して再 計算するといった操作を繰り返し，収束解が得られた時 点で, 各流量に応じた礫の露出率が得られるものとした。 対象流況については，考察の容易さ，季節変化（1年 （365日）分）による変動性を考慮してモデル化し, 図10のように与えた。 150 日目に与える $200 \mathrm{~m}^{3} / \mathrm{s}$ は，いわゆ る低水路満杯流量程度である. 以下では, 繁茂動態シ ミュレーションに当たって，2年間にわたる計算を行い， 初期条件の影響が少ない2年目の計算結果を用いる.

（2）cost benefit analysis modelを用いた生息場評価
図-11には，得られた評価值コンターの一例を示す。 異なる成長率 (1)〜 (3)) を与えた3通りの結果を表示し ている.なお，剥離率 (cost) が0の時の評価值を 1000 （凡例中の上端の值）とした. 評価値1が最大となるよ うな通常の生息適性評価値とは異なり, 最適值が不明で あるものの，相対的比較は可能である．砂州周りで評価 值が大きいというコンター図の全体的な傾向はほぼ変わ らないが，凡例中の数值により，生長率（benefit）を流 速, 水深と関連づけることにより, 評価值が低減される 様子が分かる.

\section{（3）付着藻類繁茂動態シミュレーション}

付着藻類生育の前提条件として, その場所が冠水して いる必要がある。 そこで, 初期条件としては, 対象河道 における冠水域内（流量 $30 \mathrm{~m}^{3} / \mathrm{s}$ 時）に無次元植被率 $A^{*}=0.5 （ そ れ 以$ 外は, $A^{*}{ }_{0}=0.0$ ）を与える. 流況に沿っ て計算を進めていく中で，新たに陸化した領域は $A^{*}=0.0$ とし, その後, 再び冠水した領域には $A^{*}=0.01$ をえる. また，冠水域内においては， $A^{*}=0.01$ を限とし，それ 


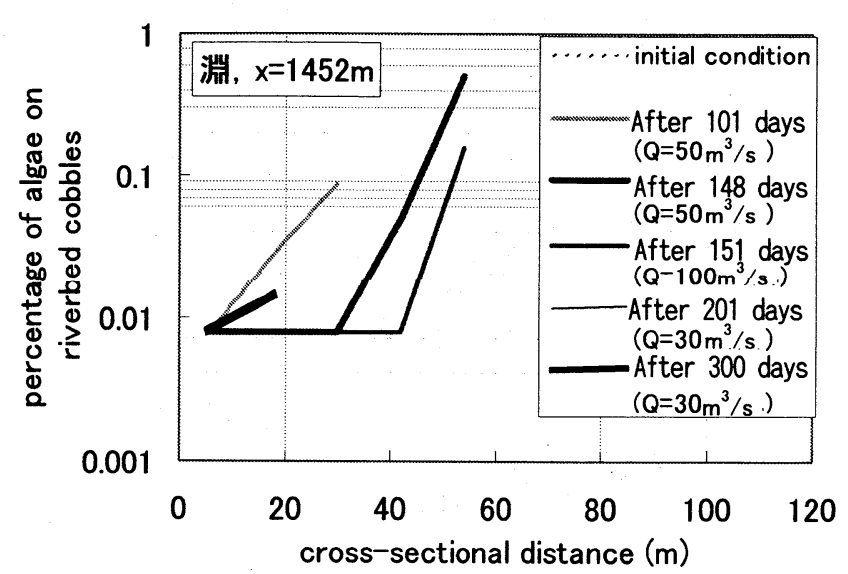

図-13 付着藻類植被率の横断分布の時間変化

以上は剥離されないものとした．また，もう一つの生育 条件として, 藻類が付着する喽は砂面から突出している 必要があるので, 砂の存在による植被可能面積の減少の 効果を, 礫の露出率 $\delta\left(=\Delta_{\mathrm{G}} / d_{\mathrm{G}}\right)$ を用いて次式で考慮した。

$$
\begin{array}{cc}
A^{*}{ }_{e}=\delta(1-\delta) \pi \cdot A^{*} & 0.0 \leq \delta \leq 0.5 \\
A^{*}{ }_{e}=\frac{\pi}{4} \cdot A^{*} & 0.5 \leq \delta
\end{array}
$$

ここに, $A_{\mathrm{e}}^{*}$ : 無次元有効植被率である. $A^{*}$ の算出は, 式(10)に従って行った。解析の結果得られた植被率コン 夕一の一例（式(4)で得られる生長率 $\varepsilon_{3}$ を採用）を図-12 に示す．いずれも，図-11と同じく，流量 $50 \mathrm{~m}^{3} / \mathrm{s}$ 時の結 果であり，対象時点を図-10中の矢印にて表す．図-12を 見ると, 中段の145日後から下段の175日後への植被率の 低減が顕著であり，150日目前後の出水による影響が表 れている．また，図-13には，植被率変化の顕著な横断 面（x=1452m地点：淵）を対象とし，植被率の横断方向 分布の時間変化を表す. デー夕のないところは，植被率 が0であることを示している. 出水によるインパクトは, 植被率を大きく低減させるが, $50 \mathrm{~m}^{3} / \mathrm{s}$ 程度の高流量は淵 での繁茂に効果がある.

\section{（4）結果の考察}

図-11と図-12を比較すると，評価値の高い範囲に植被 率が大きくなる場所が含まれているが，評価值が高くて も植被率が小さいなど，必ずしも対応していない様子が 分かる．潜在可能性を表現する生息適性評価としては， 図-11の結果は十分と考えても良いが，例えば，図-6に 示した藻類植被率の相違に見られる生息場の現状把握に は無力であり，時間的な環境変化が著しい河川域におけ る生息場の適正な評価には，生息動態予測モデルによる 図-12の方が見合っていると言えよう。
本研究では, 個体群動態モデルにおける増殖率, 剥離 率などのパラメー夕を物理環境特性と関連づけることに よって, 従来の生息場評価手法では表現できなかった生 息動態を議論できる評価手法を提案した. 今後は, 実現 象に即した各種パラメータの設定について検討する予定 である。

\section{参考文献}

1) 寺本英 : 数理生態学, 朝倉書店, 183p., 1997.

2) 浅枝隆, ズン・ソンホン, 藤野毅 : 河床ペリファイトンの遷 移過程の解析，河川技術に関する論文集，第6巻，pp.119-124， 2000 .

3) 楠田哲也 : 水域生態系モデルの進歩と課題, 第36回水工学に 関する夏季研修会講義集Aコース，pp.A-3-1-23，2000.

4) 田代喬, 伊藤壮志, 辻本哲郎 : 生活史における時間的連続性 に着目した魚類生息場の評価，河川技術論文集，第8巻， pp.277-282, 2002.

5) 辻本哲郎, 北村忠紀, 加藤万貴, 田代喬 : 低攪乱砂床におけ る大型糸状藻類繁茂のシナリオ，河川技術論文集，第8巻， pp.67-72, 2002.

6) 竹門康弘, 谷田一三, 玉置昭夫, 向井宏, 川端善一郎 : 棲み 場所の生態学, 平凡社, 279p., 1995.

7) 白金晶子：矢作川中流域における系状緑藻Cladophora glomerataのモニタリング調査一生物班報告一, 河川環境復元 総合調查研究事業（矢作川古鼠プロジェクト）平成12年度報 告書, 豊田市矢作川研究所, pp.53-60, 2001.

8) Borchardt, M. A.: Nutrients, Algal Ecology, edited by R.J. Stevenson et.al., Chapt.6, Academic Press, pp.375-402, 1996.

9) Stevensen, R. J.: The stimulation and drag of current, Algal Ecology, edited by R. J. Stevenson et al, Chapt.11, Academic Press, pp.321336, 1996.

10) Peterson, C. G.: Response of benthic algal communities to natural physical disturbance, Algal Ecology, edited by R. J. Stevenson etal, Chapt.13, Academic Press, pp.375-398, 1996.

11）田代喬, 辻本哲郎 : 河床臔乱頻度を指標とした生息場評価 による瀬・淵構造の変質に関する考察, 水工学論文集, 第46 巻, pp.1151-1156, 2002.

12) 芦田和男, 藤田正治 : 河床粒子の浮遊機構とそのモデル化, 土木学会論文集，第375号，pp.79-88，1986.

13) 道上正規, 藤田正治, 三村光太郎: 粗面河床上の平衡浮遊 砂濃度分布に関する研究，平成 4 年度土木学会中国四国支部 研究発表会, II-87, pp.264-265, 1992.

14) 芦田和男, 道上正規 : 移動床流れの抵抗と掃流砂量に関す る基礎的研究，土木学会論文集，第206号，pp59-69，1972.

15) 北村忠紀, 加藤万貴, 田代喬, 辻本哲郎 : 砂利投入による 付着藻類カワシオグサの剥離除去に関する実験的研究,河川 技術に関する論文集，Vo.6，pp.125-130, 2001 .

16) 石橋媇 : ダム排砂設備の流下砂碩による磨耗・損傷に関す る水理学的研究, 土木学会論文集, 第334号, pp.103-112, 1983.

17) 田代喬, 北村忠紀, 辻本哲郎 : Cost Benefit Analysis Modelを 用いた魚類の生息場適性の評価，第56回土木学会年次学術講 演会概要集, pp.382-383, 2001.

18) 中川博次, 辻本哲郎 : 移動床流れの水理, 技報堂出版, 1986. 